\title{
Temporal changes of coronary artery plaque located behind the struts of the everolimus eluting bioresorbable vascular scaffold
}

\author{
Salvatore Brugaletta $\cdot$ Hector M. Garcia-Garcia $\cdot$ Scot Garg $•$ Josep Gomez-Lara • \\ Roberto Diletti · Yoshinobu Onuma • Robert Jan van Geuns • Dougal McClean • \\ Dariusz Dudek · Leif Thuesen • Bernard Chevalier • Stephan Windecker • \\ Robert Whitbourn • Cecile Dorange - Karine Miquel-Hebert • Krishnankutty Sudhir • \\ John A. Ormiston • Patrick W. Serruys
}

Received: 10 June 2010/ Accepted: 29 September 2010/Published online: 13 October 2010

(C) Springer Science+Business Media, B.V. 2010

\begin{abstract}
Implantation of a coronary stent results in a mechanical enlargement of the coronary lumen with stretching of the surrounding atherosclerotic plaque. Using intravascular ultrasound virtual-histology (IVUS-VH) we examined the temporal changes in composition of the plaque behind the struts (PBS) following the implantation of the everolimus eluting bioresorbable vascular scaffold (BVS). Using IVUS$\mathrm{VH}$ and dedicated software, the composition of plaque was analyzed in all patients from the ABSORB B trial who were imaged with a commercially available IVUS-VH console (s5i system, Volcano Corporation, Rancho Cordova, CA, USA) post-treatment and at
\end{abstract}

S. Brugaletta · H. M. Garcia-Garcia .

S. Garg · J. Gomez-Lara · R. Diletti ·

Y. Onuma · R. J. van Geuns · P. W. Serruys $(\bowtie)$

Thoraxcenter, Erasmus MC, Ba-583, 's Gravendijkwal

230, 3015 CE Rotterdam, The Netherlands

e-mail: p.w.j.c.serruys@erasmusmc.nl

H. M. Garcia-Garcia

Cardialysis B.V, Rotterdam, The Netherlands

D. McClean

Chrischurch Hospital, Chrischurch, New Zealand

D. Dudek

Jagiellonian University, Krakow, Poland

L. Thuesen

Skejby Sygehus, Aarhus, Denmark 6-month follow-up. This dedicated software enabled analysis of the PBS after subtraction of the VH signal generated by the struts. The presence of necrotic core (NC) in contact with the lumen was also evaluated at baseline and follow-up. IVUS-VH data, recorded with s5i system, were available at baseline and 6-month follow-up in 15 patients and demonstrated an increase in both the area of PBS $\left(2.45 \pm 1.93 \mathrm{~mm}^{2}\right.$ vs. $3.19 \pm$ $\left.2.48 \mathrm{~mm}^{2}, P=0.005\right)$ and the external elastic membrane area $\left(13.76 \pm 4.07 \mathrm{~mm}^{2}\right.$ vs. $14.76 \pm 4.56 \mathrm{~mm}^{2}$, $P=0.006)$. Compared to baseline there was a significant progression in the $\mathrm{NC}\left(0.85 \pm 0.70 \mathrm{~mm}^{2}\right.$ vs. $\left.1.21 \pm 0.92 \mathrm{~mm}^{2}, P=0.010\right)$ and fibrous tissue area

\author{
B. Chevalier \\ Institut Cardiovasculaire Paris Sud, Massy, France \\ S. Windecker \\ Bern University Hospital, Bern, Switzerland \\ R. Whitbourn \\ St Vincents Hospital, Fitzroy, Australia \\ C. Dorange · K. Miquel-Hebert · K. Sudhir \\ Abbott Vascular, Diegem, Belgium \\ J. A. Ormiston \\ Department of Cardiology, Auckland City Hospital, \\ Auckland, New Zealand
}


$\left(0.88 \pm 0.79 \mathrm{~mm}^{2}\right.$ vs. $\left.1.15 \pm 1.05 \mathrm{~mm}^{2}, P=0.027\right)$ of the PBS. The NC in contact with the lumen in the treated segment did not increase with follow-up (7.33 vs. $6.36 \%, P=0.2$ ). Serial IVUS-VH analysis of BVStreated lesions at 6-month demonstrated a progression in the NC and fibrous tissue content of PBS.

Keywords Bioresorbable vascular scaffold . Coronary plaque $\cdot$ IVUS-VH $\cdot$ Everolimus

\section{Introduction}

Percutaneous treatment of atherosclerotic lesions has been improved by the introduction of bare- and drugeluting metallic stents [1]. Implantation of a metallic stent does not remove atherosclerotic plaque; instead the plaque is stretched during baro-trauma. The metallic stent platform and the eluted drug may affect not only the intra-stent neo-intima growth, but also the plaque behind the struts. With regards to the vascular response to a foreign body (i.e. a metallic stent), [2, 3] animal models have demonstrated that metallic stents eluting sirolimus and paclitaxel induce inflammatory changes adjacent to almost all struts [4].

Evaluation of plaque behind the metallic struts can be performed using intravascular ultrasound virtual histology (IVUS-VH), which facilitates qualitative and quantitative analyses of the plaque. Since metallic stent's struts are mistakenly recognized by IVUS$\mathrm{VH}$ as dense calcium and necrotic core, careful evaluation of the sole plaque behind the stent struts should be done to avoid any misclassification of the actual tissue [5, 6]. Previous reports using serial IVUS-VH analysis of lesions treated with drugeluting stents have demonstrated a greater frequency of "unstable lesion morphometry" at follow-up, compared with bare metal stents [7]. Temporary scaffolding with a everolimus eluting bioresorbable vascular scaffold (BVS; Abbott Vascular, Santa Clara, USA) may have differential effects on peristrut plaque, due to the polymeric nature of the fast resorbable coating made of a mixture of $L$ and $D$ racemic forms of poly-lactide [8].

Therefore, we assessed the vascular response to implantation of the BVS at 6-months follow-up using IVUS-VH, and customized software to selectively analyze the plaque behind the struts.

\section{Methods}

Study population

For the present analysis, we initially screened patients from Cohort B1 of the ABSORB trial with paired post-implantation and 6-month follow-up IVUS-VH. Briefly, ABSORB Cohort B trial enrolled patients older than 18 years, with a diagnosis of stable, unstable or silent ischemia. This trial was subdivided in two subgroups of patients: the first group (cohort B1) has to undergo invasive imaging such as QCA, IVUS, IVUS-VH and OCT at 6 and 24 months whereas the second group (cohort B2) will undergo this invasive imaging at 12 and 24 months. All lesions were de novo, in a native coronary artery with a reference vessel diameter of $3.0 \mathrm{~mm}$, with a \% diameter stenosis $\geq 50$ and $<100 \%$ and a thrombolysis in myocardial infarction (TIMI) flow grade of $\geq 1$. All lesions were treated by implantation of the BVS revision $1.1(3.0 \times 18 \mathrm{~mm})$. Major exclusion criteria were: patients presenting with an acute myocardial infarction, unstable arrhythmias or patients who had left ventricular ejection fraction $\leq 30 \%$, restenotic lesions, lesions located in the left main coronary artery, lesions involving a side branch $>2 \mathrm{~mm}$ in diameter, and the presence of thrombus or another clinically significant stenosis in the target vessel. This trial was approved by ethics committee at each participating institution and each patient gave written informed consent before inclusion.

The BVS has an amorphous poly-DL-lactide (PDLLA) coating that contains and controls the release of the anti-proliferative drug everolimus. The scaffold body is made of semi-crystalline poly-Llactide (PLLA). PLA is completely degraded via hydrolysis and bioresorbed via the Krebs cycle [8, 9].

Lesions were treated with routine interventional techniques that included mandatory pre-dilatation using a balloon shorter than the study device and $0.5 \mathrm{~mm}$ less in diameter. All patients were pretreated with aspirin and a loading dose of at least $300 \mathrm{mg}$ of clopidogrel was administered according to local hospital practise. After the procedure, all patients received aspirin $\geq 75 \mathrm{mg}$ for the study duration (5 years) and clopidogrel $75 \mathrm{mg}$ daily for a minimum of 6 months. Anticoagulation and glycoprotein IIb/IIIa use was according to local hospital practice. 
Imaging procedure and acquisition

IVUS-VH post-implantation and 6 months follow-up were acquired with a phased array $20 \mathrm{MHz}$ intravascular ultrasound catheter (EagleEye $^{\mathrm{TM}}$; Volcano Corporation, Rancho Cordova, CA, USA) using an automated pullback of $0.5 \mathrm{~mm}$ per second. These files were stored on DVD and sent to the Corelab for independent analyses (Cardialysis, BV, Rotterdam, The Netherlands).

Image analysis

Customized offline IVUS-VH software was the QIVUs (Medis, Leiden, The Netherlands). Unlike other IVUS-VH software (pcVH and VIAS), this package allows the user to draw, in a semi-automatic fashion, a third contour (i.e. the scaffold contour). One limitation, however, is the ability of the software to read only IVUS-VH data acquired using a specific commercially available IVUS-VH console (s5i system, Volcano Corporation, Rancho Cordova, CA, USA). Contour detection was performed by experienced IVUS analysts who were blinded to the time of acquisition of the data (e.g. baseline or 6-month follow-up) [10]. Four tissue components (necrotic core-red; dense calcium-white; fibrous-green; and fibrofatty-light green) were identified with autoregressive classification systems. Each individual tissue component was quantified and colour coded in all IVUS cross sections as previously described $[8,11]$.

It has already been reported that the polymeric struts of the BVS (150 $\mu \mathrm{m}$ strut's thickness) are misinterpreted by IVUS-VH as areas of apparent "dense calcium" and "necrotic core", [8] therefore drawing this third contour, behind the polymeric struts of the BVS, delineates a new region of interest excluding the polymeric struts and their ultrasonic signature (Fig. 1).

In addition, we evaluated the presence of necrotic core in contact with the lumen, defined as a confluent necrotic core $>10 \%$ of plaque area without evidence of overlying non-necrotic core tissue in the treated segment and in the edges $(5 \mathrm{~mm}$ length adjacent to each BVS edge). Importantly, as polymeric struts are recognized as dense calcium surrounded by necrotic core, this surrounding necrotic core identified with the help of the corresponding grey-scale image, was not interpreted as necrotic core in contact with the lumen $[5,7,12]$.

Ultimately, we drew the interface between plaque + media and the adventitia (external elastic membrane area, EEM), as well as the contours of the BVS area. We calculated the plaque area behind the struts (PBS) as the sum of all IVUS-VH components of the plaque behind the struts, excluding the grey medial stripe seen with IVUS-VH.

\section{Statistical analysis}

Discrete variables are presented as counts and percentages. Continuous variables are presented as means \pm standard deviation (SD). The calculation of the changes of each IVUS-VH plaque component between post-treatment and 6 months was as follows: mean 6 months area minus mean post-procedure area. The ratio between the number of frames with necrotic core in contact with the lumen and the total number of frames analyzed has been defined as incidence of necrotic core in contact with the lumen for the treated segment and the edges. Paired comparisons between

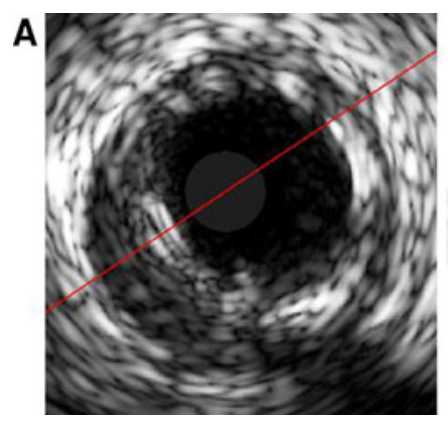

Fig. 1 Panel A: one frame of grey-scale IVUS indicating the appearance of the BVS's struts (double grey line). In Panel B the polymeric struts are recognized as dense calcium and

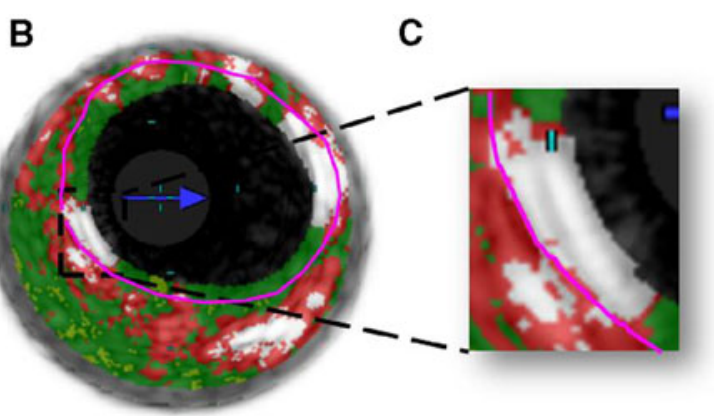

necrotic core by IVUS-VH and in (Panel $C$ ) a third contour (purple line) is drawn in a semi-automatic way by the dedicated software behind them 
post-procedure and 6-month follow-up were done by the Wilcoxon signed rank test. Correlation between parameters was performed by Spearman test. A twoside $P$ value of less than 0.05 indicated statistical significance. Intra-observer and inter-observer variabilities were measured by correlation test for IVUS data and by $\kappa$ test of concordance for necrotic core in contact with the lumen. Statistical analyses were performed with use of SPSS 13.0 software.

\section{Results}

Baseline clinical and angiographic characteristics

Thirty-two patients in the ABSORB Cohort B study had paired post- implantation and 6-month IVUS-VH

Table 1 Clinical and angiographic characteristics of the patients

Patients $(n=15)$

Lesions $(n=15)$

\begin{tabular}{lc} 
Age (years) & \\
Mean \pm SD $(n)$ & $63.87 \pm 12.01$ \\
Men $(\%)$ & 60.0 \\
Smokers (\%) & 26.7 \\
Diabetes (\%) & 13.3 \\
Hypertension requiring medication (\%) & 66.7 \\
Hyperlipidaemia requiring medication $(\%)$ & 80.0 \\
Previous target vessel intervention $(\%)$ & 6.7 \\
Previous myocardial infarction (\%) & 53.3 \\
Stable angina (\%) & 53.3 \\
Unstable angina (\%) & 33.3 \\
Silent ischaemia (\%) & 6.7 \\
Target vessel (\%) & \\
Left anterior descending & 33.3 \\
Left circumflex & 26.7 \\
Right coronary artery & 40.0 \\
AHA/ACC lesion classification $(\%)$ & \\
A & 6.7 \\
B1 & 63.3 \\
B2 & 40.0 \\
C & 40.0 \\
Beta-blocker & 100.0 \\
ACEI/ARB & 53.3 \\
Calcium-channel blocker & \\
Statin & \\
& \\
\hline
\end{tabular}

$S D$ standard deviation; $A C E I$ angiotensin-converting enzyme inhibitor; $A R B$ angiotensin receptor blocker data. Out of these 32 patients, only 15 patients were imaged using the s5i system. Table 1 shows their clinical and angiographic data.

Grey-scale IVUS and IVUS-VH analyses (Table 2)

A significant increase in both EEM area and of PBS was observed with follow-up. A non significant $4 \%$ decrease in BVS area was observed at follow up $(P=0.065)$.

In the IVUS-VH analysis of the plaque behind the polymeric struts, there was a significant relative increase of $30 \%$ in fibrous tissue area (from $0.88 \pm 0.79 \mathrm{~mm}^{2}$ to $\left.1.15 \pm 1.05 \mathrm{~mm}^{2} ; P=0.027\right)$ and of $42 \%$ in necrotic core area (from $0.85 \pm$ $0.70 \mathrm{~mm}^{2}$ to $\left.1.21 \pm 0.92 \mathrm{~mm}^{2} ; P=0.010\right)$ at 6 month follow-up. There was a no significant increase of $3 \%$ in fibrofatty tissue area $(P=0.286)$ and $8 \%$ in dense calcium area $(P=0.334)$. However, the percentage weight of each plaque component did not change significantly.

There was a significant correlation between $\Delta$ plaque behind the polymeric struts and $\Delta$ mean EEM area $(r=0.9, \quad P<0.001 ;$ Fig. 2$)$ There was no

Table 2 IVUS analysis in the treated segment at baseline and follow-up

\begin{tabular}{|c|c|c|c|}
\hline & \multicolumn{2}{|c|}{ BVS $1.1(n=15)$} & \multirow[t]{2}{*}{$P$ value } \\
\hline & Baseline & Follow-up & \\
\hline $\begin{array}{l}\text { Mean EEM area } \\
\left(\mathrm{mm}^{2}\right)\end{array}$ & $13.76 \pm 4.07$ & $14.76 \pm 4.56$ & 0.006 \\
\hline PBS area $\left(\mathrm{mm}^{2}\right)$ & $2.45 \pm 1.93$ & $3.19 \pm 2.48$ & 0.005 \\
\hline BVS area $\left(\mathrm{mm}^{2}\right)$ & $6.51 \pm 1.38$ & $6.25 \pm 1.14$ & 0.065 \\
\hline Fibrous tissue $\left(\mathrm{mm}^{2}\right)$ & $0.88 \pm 0.79$ & $1.15 \pm 1.05$ & 0.027 \\
\hline Fibrous tissue $(\%)$ & $38.80 \pm 16.36$ & $35.86 \pm 13.25$ & 0.256 \\
\hline $\begin{array}{l}\text { Fibro-fatty tissue } \\
\left(\mathrm{mm}^{2}\right)\end{array}$ & $0.18 \pm 0.36$ & $0.20 \pm 0.40$ & 0.286 \\
\hline $\begin{array}{l}\text { Fibro-fatty tissue } \\
(\%)\end{array}$ & $5.31 \pm 7.82$ & $4.43 \pm 6.70$ & 0.532 \\
\hline Necrotic core $\left(\mathrm{mm}^{2}\right)$ & $0.85 \pm 0.70$ & $1.21 \pm 0.92$ & 0.010 \\
\hline Necrotic core $(\%)$ & $37.23 \pm 11.66$ & $40.18 \pm 8.69$ & 0.307 \\
\hline $\begin{array}{l}\text { Dense calcium } \\
\quad\left(\mathrm{mm}^{2}\right)\end{array}$ & $0.54 \pm 0.85$ & $0.62 \pm 0.72$ & 0.334 \\
\hline Dense calcium (\%) & $18.66 \pm 14.06$ & $19.52 \pm 12.77$ & 0.691 \\
\hline
\end{tabular}

Data are expressed as mean $\pm \mathrm{SD}$

$E E M$ external elastic membrane; $P B S$ plaque behind struts; $B V S$ bioresorbable vascular scaffold 


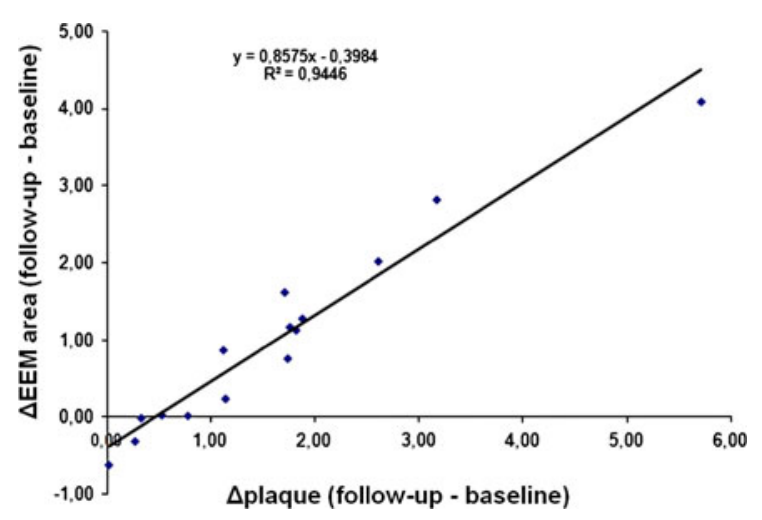

Fig. 2 Correlation between the temporal change of the plaque behind the polymeric struts and of EEM area. EEM external elastic membrane

correlation between $\Delta$ plaque behind the struts and the change in BVS area $(P=0.9)$.

Incidence of necrotic core in contact with the lumen

A representative IVUS image of necrotic core in contact with the lumen in the BVS treated segment is shown in Fig. 3. There was no significant change during follow-up in the content of the necrotic core in contact with the lumen in the treated segment $(7.33$ vs. $6.36 \%, P=0.256$; Fig. 4 ).

Intra-observer and inter-observer variabilities

Intra-observer and inter-observer variabilities yielded good concordance for IVUS data $\left(r^{2}=0.91\right.$ and

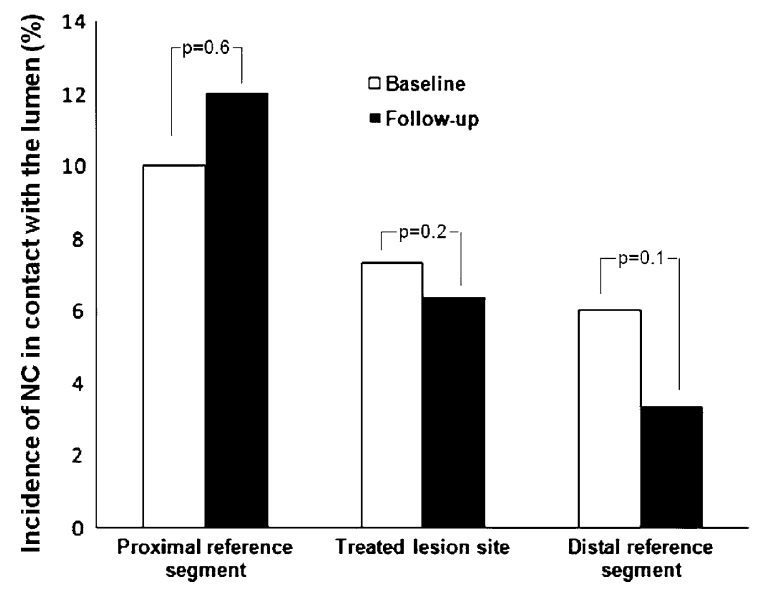

Fig. 4 Incidence of segments with necrotic core abutting the lumen at baseline and follow-up. Within the treated lesion site, proximal and distal reference segment necrotic core abutting the lumen did not significantly modify

$r^{2}=0.87$, respectively) and for necrotic core in contact with the lumen ( $\kappa=0.96$ and $\kappa=0.90$, respectively)

\section{Discussion}

The major findings of our study are: (1) at 6 months follow-up, the increase in plaque area, and in particular the progression of necrotic core and fibrous tissue detected by IVUS-VH behind the polymeric struts, correlated to an increase in EEM area; (2) although there was an increase in necrotic core area behind the polymeric struts, there was not an increase in necrotic core in contact with the lumen in the treated segment.

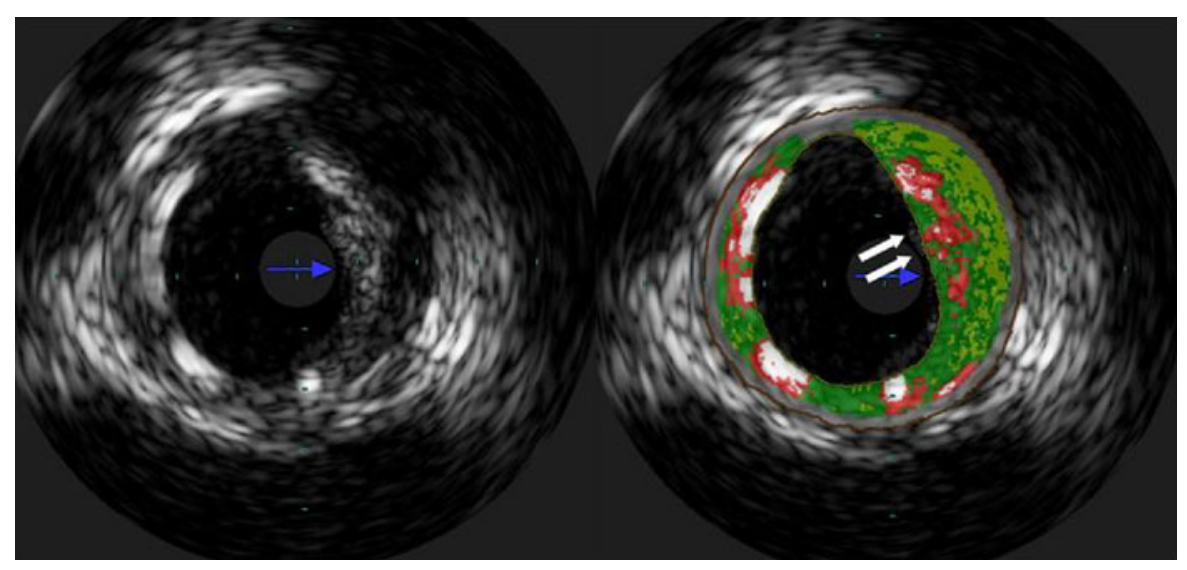

Fig. 3 Representative IVUS-VH image of necrotic core in contact with the lumen in the segment where a BVS has been implanted (white arrows). BVS bioresorbable polymeric scaffold 
Similar to metallic stents, struts of the BVS are detected by IVUS-VH as dense calcium, surrounded by a "red halo" [5, 12]. This observation may be useful for the evaluation of the bioresorption process of the BVS, as temporal changes in dense calcium and necrotic core of coronary segments treated with a BVS appear to be a 'surrogate' of the bioresorption process $[6,12]$. However, this misinterpretation of the polymeric struts by IVUS-VH prevents analysis of the actual amount of dense calcium and necrotic core within the plaque behind the struts. The semiautomatic introduction by the "Medis software" of a third contour, which represents the BVS, is a helpful tool to focus analysis on only the plaque behind the BVS. We acknowledge that this software has not previously validated for this use and in our analysis it has shown a good the inter- and intra-observers variabilities.

Previously Kubo et al. analyzed the long-term effects of drug-eluting stents (DES) and bare metal stents (BMS) on coronary arterial wall morphology using IVUS-VH, and demonstrated that DES-treated lesions had a greater frequency of "unstable lesion morphometry" at follow-up compared to BMS [7]. In particular assessing the total amount of the four IVUS-VH components, including also the contribution of the stent, it was found that DES-treated lesions showed a significantly higher incidence of necrotic core in contact with the lumen compared to BMStreated lesions at follow up, although there was no significant difference in mean necrotic core area between both groups. This was due to a suppression of the protective neointimal hyperplasia layer with DES compared with BMS. In our study, focusing only on plaque burden behind the polymeric struts, we found a significant progression in necrotic core and fibrous tissue at 6 months follow-up. However, the incidence of necrotic core in contact with the lumen behind polymeric struts did not tend to increase during the same period. Histological validation studies have shown that necrotic core is a mainly highly lipid necrotic region with remnants of foam cells and some infiltration of inflammatory cells. It is unlikely that the changes described in the plaque behind the polymeric struts are influenced by changes in the BVS struts during the first 6 months: it has been, indeed, shown that the $100 \%$ of the boxes of the BVS, evaluated by optical coherence tomography, are preserved with completely absence of qualitative alterations, whereas only $3 \%$ of the boxes of the first BVS generation appeared as "preserved" [13].

Recently concerns have been raised over the longterm biological reaction to metallic DES [14]. In rabbit iliac arteries, evidence of increased inflammation and delayed endothelialization was noted at 28 days in DES compared with polymer-coated inert stents or BMS [15]. In porcine coronary arteries treated with DES, arterial inflammation characterized by giant cells has been shown to gradually progress from 90 to 180 days with a corresponding increase in neointimal formation [16]. In humans, Aoki et al. have demonstrated in vivo that plaque volume behind a metallic stent eluting sirolimus increases slightly at 4 months follow-up, and then significantly decreases at 4 years follow-up compared to post-implantation, and that change in echogenicity is suggestive of a change in plaque composition [17]. The same phenomenon was observed following implantation of an everolimuseluting metallic stent in the SPIRIT I study: slight increase of plaque behind the stent at 6 months, followed by a decrease at 1 year follow-up [18]. Aoki et al. also documented a significant increase in plaque area behind metallic stents eluting paclitaxel at 6 months, with subsequent regression at 2 years [19]. In the MAHOROBA study, that tested biodegradable polymer sustained release tacrolimus-eluting stent, Onuma et al. have shown that plaque volume increased significantly at 4-month angiographic follow-up [20]. In our study, at 6 months follow-up, we observed an increase of both plaque area and of necrotic core behind the polymeric struts of BVS.

Some preclinical studies in an atherosclerotic rabbit model have shown that the implantation of metallic everolimus eluting stents results in an autophagic process of macrophages through the inhibition of the mTOR pathway by everolimus $[21,22]$. In a porcine model, Onuma et al. found inflammatory cells, in particular granuloma and giant cells, surrounding the polymeric struts of the BVS: the concentration of cells was highest 1 and 6 months after implantation, before decreasing over time [23]. In particular after 1 year there was a decrease in the inflammation score, granulomas and giant cells surrounding the polymeric struts. It is important to highlight that in the porcine coronary artery model, BVS associated inflammation is markedly less than with a sirolimus-eluting metallic stent. In humans at 6 months after BVS 1.0 implantation and with long-term follow-up Sarno et al. found 
a similar increase of plaque area at 6-month, with a following decrease at 2 years, most likely due to the bioresorption of the polymeric struts [6].

It is also important to consider that the increase in plaque area, as a result mainly of necrotic core and fibrous tissue progression, did not translate into a decrease of a scaffold area of BVS, but only in a positive remodelling of the EEM [24]. RodriguezGranillo et al. have already shown how positive remodelling of the vessel may be related to plaque composition: in particular lipid core size was significantly larger in positively remodelled coronary lesions than in those with vessel shrinkage [24].

\section{Limitations}

The present study included a very small number of patients with a technique (VH) that has large variability. The use of the same patients at baseline and followup may reduce its variability. However, the intra- and inter-catheter variability of the $\mathrm{VH}$ previously shown supports longitudinal studies with the VH [25].

IVUS-VH data pre-BVS implantation were not available, therefore baseline characteristics of the artery have been evaluated in the presence of the BVS, and after pre-dilatation.

The interpretation of the backscattering signal from the plaque behind the polymeric struts by the IVUSVH software may be influenced by the presence of the scaffold: analysis of the difference between 6-month follow-up and baseline may reduce this limitation.

\section{Conclusions}

In conclusion our study focusing on the IVUS-VH detection of plaque behind the BVS seems to show a progression in necrotic core and fibrous tissue components at 6 months. In particular, the progression in necrotic core confirms the histological data in animal models regarding an inflammatory microenvironment behind the polymeric struts, at least at 6-month follow-up.

\section{References}

1. Moses JW, Leon MB, Popma JJ, Fitzgerald PJ, Holmes DR, O'Shaughnessy C, Caputo RP, Kereiakes DJ,
Williams DO, Teirstein PS, Jaeger JL, Kuntz RE (2003) Sirolimus-eluting stents versus standard stents in patients with stenosis in a native coronary artery. N Engl J Med 349(14):1315-1323. doi:10.1056/NEJMoa035071349/14/ 1315 [pii]

2. Finn AV, Nakazawa G, Joner M, Kolodgie FD, Mont EK, Gold HK, Virmani R (2007) Vascular responses to drug eluting stents: importance of delayed healing. Arterioscler Thromb Vasc Biol 27(7):1500-1510. doi:ATVBAHA. 107.144220[pii]10.1161/ATVBAHA.107.144220

3. Joner M, Finn AV, Farb A, Mont EK, Kolodgie FD, Ladich E, Kutys R, Skorija K, Gold HK, Virmani R (2006) Pathology of drug-eluting stents in humans: delayed healing and late thrombotic risk. J Am Coll Cardiol 48(1): 193-202. doi:S0735-1097(06)01109-0[pii]10.1016/j.jacc. 2006.03.042

4. Wilson GJ, Nakazawa G, Schwartz RS, Huibregtse B, Poff B, Herbst TJ, Baim DS, Virmani R (2009) Comparison of inflammatory response after implantation of sirolimus- and paclitaxel-eluting stents in porcine coronary arteries. Circulation 120(2):141-149, 141-142. doi:CIRCULATIONAHA.107.730010 [pii]10.1161/CIRCULATIONAHA.107. 730010

5. Kim SW, Mintz GS, Hong YJ, Pakala R, Park KS, Pichard AD, Satler LF, Kent KM, Suddath WO, Waksman R, Weissman NJ (2008) The virtual histology intravascular ultrasound appearance of newly placed drug-eluting stents. Am J Cardiol 102(9):1182-1186. doi:S0002-9149(08) 00567-5[pii]10.1016/j.amjcard.2008.03.054

6. Sarno G, Onuma Y, Garcia HM, Garg S, Regar E, Thuesen L, Dudek D, Veldhof S, Dorange C, Ormiston JA, Serruys PW (2010) Ivus radiofrequency analysis in the evaluation of the polymeric struts of the bioabsorbable everolimus-eluting device during the bioabsorption process. Catheter Cardiovasc Interv 5:627-632. doi:10. $1002 / \mathrm{ccd} .22332$

7. Kubo T, Maehara A, Mintz GS, Garcia-Garcia HM, Serruys PW, Suzuki T, Klauss V, Sumitsuji S, Lerman A, Marso SP, Margolis MP, Margolis JR, Foster MC, De Bruyne B, Leon MB, Stone GW (2010) Analysis of the long-term effects of drug-eluting stents on coronary arterial wall morphology as assessed by virtual histology intravascular ultrasound. Am Heart J 159(2):271-277. doi:S0002-8703(09)00880-1 [pii]10.1016/j.ahj.2009.11.008

8. Serruys PW, Ormiston JA, Onuma Y, Regar E, Gonzalo N, Garcia-Garcia HM, Nieman K, Bruining N, Dorange C, Miquel-Hebert K, Veldhof S, Webster M, Thuesen L, Dudek D (2009) A bioabsorbable everolimus-eluting coronary stent system (absorb): 2-year outcomes and results from multiple imaging methods. Lancet 373(9667): 897-910. doi:S0140-6736(09)60325-1[pii]10.1016/S0140-6736 (09)60325-1

9. Ormiston JA, Serruys PW, Regar E, Dudek D, Thuesen L, Webster MW, Onuma Y, Garcia-Garcia HM, McGreevy R, Veldhof S (2008) A bioabsorbable everolimus-eluting coronary stent system for patients with single de novo coronary artery lesions (absorb): a prospective open-label trial. Lancet 371(9616):899-907. doi:S0140-6736(08) 60415-8[pii]10.1016/S0140-6736(08)60415-8

10. Hausmann D, Lundkvist AJ, Friedrich GJ, Mullen WL, Fitzgerald PJ, Yock PG (1994) Intracoronary ultrasound 
imaging: intraobserver and interobserver variability of morphometric measurements. Am Heart J 128(4):674-680

11. Nair A, Kuban BD, Tuzcu EM, Schoenhagen P, Nissen SE, Vince DG (2002) Coronary plaque classification with intravascular ultrasound radiofrequency data analysis. Circulation 106(17):2200-2206

12. Garcia-Garcia HM, Gonzalo N, Pawar R, Kukreja N, Dudek D, Thuesen L, Ormiston JA, Regar E, Serruys PW (2009) Assessment of the absorption process following bioabsorbable everolimus-eluting stent implantation: temporal changes in strain values and tissue composition using intravascular ultrasound radiofrequency data analysis. A substudy of the absorb clinical trial. EuroIntervention 4(4):443-448

13. Serruys PW, Onuma Y, Ormiston JA, De Bruyne B, Regar E, Dudek D, Thuesen L, Smith P, Chevalier B, McClean D, Koolen J, Windecker S, Whitbourn R, Meredith I, Dorange C, Veldhof S, Miquel-Hebert K, Rapoza R, Garcia Garcia HM (2010) Evaluation of the second generation of a bioresorbable everolimus drug-eluting vascular scaffold for treatment of de novo coronary artery stenosis: 6-month clinical and imaging outcomes. Circulation (in press)

14. Virmani R, Liistro F, Stankovic G, Di Mario C, Montorfano M, Farb A, Kolodgie FD, Colombo A (2002) Mechanism of late in-stent restenosis after implantation of a paclitaxel derivate-eluting polymer stent system in humans. Circulation 106(21):2649-2651

15. Klugherz BD, Llanos G, Lieuallen W, Kopia GA, Papandreou G, Narayan P, Sasseen B, Adelman SJ, Falotico R, Wilensky RL (2002) Twenty-eight-day efficacy and phamacokinetics of the sirolimus-eluting stent. Coron Artery Dis 13(3):183-188

16. Carter AJ, Aggarwal M, Kopia GA, Tio F, Tsao PS, Kolata R, Yeung AC, Llanos G, Dooley J, Falotico R (2004) Long-term effects of polymer-based, slow-release, sirolimus-eluting stents in a porcine coronary model. Cardiovasc Res 63(4):617-624. doi:10.1016/j.cardiores.2004.04.029 S0008636304002019[pii]

17. Aoki J, Abizaid AC, Serruys PW, Ong AT, Boersma E, Sousa JE, Bruining N (2005) Evaluation of four-year coronary artery response after sirolimus-eluting stent implantation using serial quantitative intravascular ultrasound and computer-assisted grayscale value analysis for plaque composition in event-free patients. J Am Coll Cardiol 46(9):1670-1676. doi:S0735-1097(05)01846-2 [pii]10.1016/j.jacc.2005.06.076

18. Tsuchida K, Piek JJ, Neumann FJ, van der Giessen WJ, Wiemer M, Zeiher AM, Grube E, Haase J, Thuesen L, Hamm CW, Veldhof S, Dorange C, Serruys PW (2005)
One-year results of a durable polymer everolimus-eluting stent in de novo coronary narrowings (the spirit first trial). EuroIntervention 1(3):266-272. doi:EIJV1I3A44[pii]

19. Aoki J, Colombo A, Dudek D, Banning AP, Drzewiecki J, Zmudka K, Schiele F, Russell ME, Koglin J, Serruys PW (2005) Peristent remodeling and neointimal suppression 2 years after polymer-based, paclitaxel-eluting stent implantation: insights from serial intravascular ultrasound analysis in the taxus ii study. Circulation 112(25): 3876-3883. doi:CIRCULATIONAHA.105.558601[pii]10. 1161/CIRCULATIONAHA.105.558601

20. Onuma Y, Serruys P, den Heijer P, Joesoef KS, Duckers H, Regar E, Kukreja N, Tanimoto S, Garcia-Garcia HM, van Beusekom H, van der Giessen W, Nishide T (2009) Mahoroba, first-in-man study: 6-month results of a biodegradable polymer sustained release tacrolimus-eluting stent in de novo coronary stenoses. Eur Heart J 30(12): 1477-1485. doi:ehp127[pii]10.1093/eurheartj/ehp127

21. Verheye S, Martinet W, Kockx MM, Knaapen MW, Salu K, Timmermans JP, Ellis JT, Kilpatrick DL, De Meyer GR (2007) Selective clearance of macrophages in atherosclerotic plaques by autophagy. J Am Coll Cardiol 49(6): 706-715. doi:S0735-1097(06)02888-9[pii]10.1016/j.jacc.2006. 09.047

22. Martinet W, Verheye S, De Meyer GR (2007) Everolimusinduced mtor inhibition selectively depletes macrophages in atherosclerotic plaques by autophagy. Autophagy 3(3): 241-244. doi:3711[pii]

23. Onuma Y, Serruys PW, Perkins L, Okamura T, Gonzalo N, Garcia HM, Regar E, Kamberi M, Powers JC, Rapoza R, van Beusekom H, van der Giessen W, Virmani R Intracoronary optical coherence tomography (oct) and histology at 1 month, at 2, 3 and 4 years after implantation of everolimus-eluting bioresorbable vascular scaffolds in a porcine coronary artery model: an attempt to decipher the human oct images in the absorb trial. Circulation (in press)

24. Rodriguez-Granillo GA, Serruys PW, Garcia-Garcia HM, Aoki J, Valgimigli M, van Mieghem CA, McFadden E, de Jaegere PP, de Feyter P (2006) Coronary artery remodelling is related to plaque composition. Heart 92(3):388-391. doi:hrt.2004.057810[pii]10.1136/hrt.2004.057810

25. Rodriguez-Granillo GA, Vaina S, Garcia-Garcia HM, Valgimigli M, Duckers E, van Geuns RJ, Regar E, van der Giessen WJ, Bressers M, Goedhart D, Morel MA, de Feyter PJ, Serruys PW (2006) Reproducibility of intravascular ultrasound radiofrequency data analysis: implications for the design of longitudinal studies. Int $\mathbf{J}$ Cardiovasc Imaging 22(5):621-631. doi:10.1007/s10554006-9080-0 